\title{
Hibiscus Leaf Tissue Nutrient Sufficiency Ranges by Chronological Age
}

\author{
William Garrett Owen ${ }^{1}$ \\ Department of Horticulture, Michigan State University, 1066 Bogue Street, \\ East Lansing, MI 48824; and Tollgate Farm and Education Center, Michigan \\ State University Extension, 28115 Meadowbrook Road, Novi, MI 48377
}

Additional index words. greenhouse production, macronutrient, micronutrient, nitrogen, perennial, plant nutrition

\begin{abstract}
Perennial hibiscus (Hibiscus sp.) are popular summer-flowering plants that are grown in greenhouses or nurseries, where growers must optimize production inputs such as fertility to maximize plant growth and produce high-quality flowering crops. The objective of this study was to determine the optimum fertilizer concentrations, identify leaf tissue nutrient sufficiency ranges by chronological age, and to expand leaf tissue nutrient standards of Hibiscus hybrid L. (hibiscus) grown in soilless substrates during container production. Two cultivars of hibiscus $(\boldsymbol{H}$. hybrid $\mathbf{L}$. 'Mocha Moon' and 'Starry Starry Night') were grown under one of six constant liquid fertilizer concentrations [50, $75,100,200,300$, or $400 \mathrm{mg} \cdot \mathrm{L}^{-1}$ nitrogen $\left.(\mathrm{N})\right]$ with a constant level of water-soluble micronutrient blend in a greenhouse. The fertilizer concentrations sufficient for optimal plant growth and development were determined by analyzing plant height, diameter, growth index (GI), primary shoot caliper (PSC), and total dry mass, and they were found to be $100-300 \mathrm{mg} \cdot \mathrm{L}^{-1} \mathrm{~N}$ after an 8-week crop cycle. Recently, mature leaf tissue samples were collected and analyzed for elemental content of 12 nutrients at 2, 4, 6, and 8 weeks after transplant (WAT) from plants fertilized with $100-300 \mathrm{mg} \cdot \mathrm{L}^{-1} \mathrm{~N}$. An overall trend of increasing sufficient tissue concentration over time was observed for total $N$, phosphorus (P), calcium (Ca), sulfur (S), zinc ( $\mathrm{Zn})$, copper (Cu), and boron (B), whereas a decreasing trend was observed for potassium (K), iron (Fe), manganese (Mn), and aluminum (Al). For instance, at 2 WAT, total $\mathrm{N}$ ranged from $3.1 \%$ to $5.1 \% \mathrm{~N}$ and increased to a range of $4.2 \%$ to $4.7 \% \mathrm{~N}$ at 8 WAT. At 2 WAT, Fe and Mn ranged from 79.2 to $103.6 \mathrm{mg} \cdot \mathrm{L}^{-1} \mathrm{Fe}$ and $66.3-82.8 \mathrm{mg} \cdot \mathrm{L}^{-1} \mathrm{Mn}$ and decreased to ranges of $75.6-82.9$ $\mathrm{mg} \cdot \mathrm{L}^{-1} \mathrm{Fe}$ and $18.1-99.7 \mathrm{mg} \cdot \mathrm{L}^{-1} \mathrm{Mn}$ at $8 \mathrm{WAT}$, respectively. Optimal leaf tissue concentration sufficiency ranges determined in this scientifically-based study were narrower than previously reported survey values for the genera Hibiscus.
\end{abstract}

Over the past decade, the United States herbaceous perennial sector, including garden chrysanthemum (Chrysanthemum $\times$ morifolium Ramat.) and hosta (Hosta Tratt. sp.) categories, increased by $43 \%$ from 2005 to 2015 (USDA, $2006,2016)$. To meet this increasing consumer demand for herbaceous perennials, producers

\footnotetext{
Received for publication 10 Aug. 2018. Accepted for publication 26 Dec. 2018

I gratefully acknowledge Darby Anderson, Melanie Connors, and Kyle Martin for greenhouse assistance; and the Americana Foundation and Michigan State University College of Agriculture and Natural Resources for greenhouse space and maintenance. I thank Walters Gardens, Inc. for plant material; Barson's Greenhouse for substrate; Bordine's Farm for fertilizer; and the Fred C. Gloeckner Foundation, Inc. and Michigan State University Extension Agriculture and Agribusiness Institute (AABI) Generating Research and Extension to meet Economic and Environmental Needs (GREEEN) Research for funding support.

The use of trade names in this publication does not imply endorsement by Michigan State University or Michigan State University Extension of products named nor criticism of similar ones not mentioned. ${ }^{1}$ Corresponding author. E-mail: wgowen@msu. edu.
}

must optimize production inputs, understand environmental and cultural requirements, and minimize waste, thereby, consistently producing high-quality flowering crops. However, much of the literature available to perennial growers were established from research that occurred in the late 1990 s to early 2000 s and included propagation (Enfield, 2002), cold hardiness and overwintering [acclimation, freezing, and deacclimation (Herrick and Perry, 1997; Kingsley-Richards and Perry, 2011; Perry, 2011)], and forcing [vernalization, photoperiod, and temperature (Heins et al., 2000)] studies. Since then, new and ongoing herbaceous perennial research has surfaced including, propagation (Owen, 2017) and plant growth control (Latimer, 2016) studies, respectively.

To date, optimum fertilization requirements (Owen et al., 2013; Scoggins, 2005) and nutritional leaf tissue sufficiency ranges and standards (Barnes, 2010; Biernbaum and Morrison, 2000; Bryson and Mills, 2014; Dole and Wilkins, 2005; Zheng and Clark, 2013) of some herbaceous perennials have been reported. The largest collection of nutritional leaf tissue standards was established by Bryson and Mills (2014), but only $69 \%$ of the herbaceous perennial genera reported had tissue samples that represent containergrown plants in greenhouse or nursery production. These published leaf tissue nutritional standards established for container-grown herbaceous perennials represent survey measurements, which provide a wide variability of recommended nutrient levels. Although more than half of the herbaceous perennial leaf tissue nutritional standards represent plants grown in containers, other perennial genera tissue samples were collected from plants grown in mineral soils located in botanical gardens, arboretums, experimental plots, or were field-grown (Bryson and Mills, 2014). Therefore, these nutritional standards do not accurately represent the nutritional status nor sufficiency ranges of herbaceous perennials grown by commercial operations in soilless substrates.

Little attention has been given to identifying nutrient requirements and nutritional status of container-grown plants as related to plant age or stage of development (Tolman et al., 1990). For instance, Bryson and Mills (2014) reported an estimated age and where the leaf tissue was sampled by stating "mature leaves from new growth," while Campbell (2000) only reported leaf tissue standards for poinsettia (Euphorbia pulcherrima Willd. ex Klotzsch) at "all growth stages." However, for economically significant agronomic crops, such as corn (Zea mays L.), leaf nutrient sufficiency ranges were documented at the seedling $(<4$ inches $)$, early growth $(>4$ inches to tasseling), tasseling/bloom, and maturity developmental stages (Campbell, 2000). In annual bedding plants, leaf tissue nutrient sufficiency ranges by chronological age have been reported for pot gerbera (Gerbera jamesonii Bolus ex Hook. f. 'Festival Light Eye Yellow'; Jeong et al., 2009), osteospermum (Osteospermum hybrida L. 'Lemon Symphony', 'Serenity Lavender Dark', 'Summertime Red Velvet', and 'Tradewinds Purple Bicolor'; Papineau and Krug, 2014), and zonal geranium (Pelargonium $\times$ hortorum L.H. Bailey 'Tango Dark Red' and 'Rocky Mountain Dark Red'; Krug et al., 2010). Determining sufficiency ranges and leaf nutritional standards by chronological age for herbaceous perennials will establish nutrient recommendations that may aid in identifying nutritional deficiencies, toxicities or both. In addition, reporting of such information will establish optimal fertilizer recommendations. This is significant for commercial production because perennial growers provide plants anywhere from 50 to $700 \mathrm{mg} \cdot \mathrm{L}^{-1} \mathrm{~N}$ (Pilon, 2006). Established fertilizer recommendations will enable the potential avoidance of excess fertilization, leaching, and runoff contamination from container-grown herbaceous perennials in greenhouses or nurseries.

Thus, there is a need to establish optimum fertilization concentrations and expand leaf tissue nutritional standards for successful herbaceous perennial production. There is little information available regarding optimum fertility requirements for containergrown herbaceous perennials. Established 
leaf tissue nutritional standards are limited to only 73 herbaceous perennial genera grown in containers (Bryson and Mills, 2014), and to date, herbaceous perennial leaf tissue nutritional sufficiency ranges by chronological age have not been reported. Therefore, the objectives of this study were to determine the optimum fertilizer concentrations, identify leaf tissue nutrient sufficiency ranges by chronological age, and to expand leaf tissue nutrient standards of $H$. hybrid L. (hibiscus) grown in soilless substrates during container production. Hibiscus served as a model crop because to date, no leaf tissue concentration limits are published for $H$. hybrid, but only survey measurements taken from greenhouse- and nursery-grown hibiscus species are reported by Bryson and Mills (2014).

\section{Materials and Methods}

Plant material and culture. On 8 Apr. 2017, rooted 72-cell plug trays (30.7-mL individual cell volume) of two cultivars of hibiscus (H. hybrid L. 'Mocha Moon' and 'Starry Starry Night') were received from a commercial supplier (Walters Gardens, Inc., Zeeland, MI). Young plants of each cultivar with similar heights, stem calipers, and node numbers were selected and transplanted one plant per $16.5-\mathrm{cm}$ (1.9-L) diameter container (Landmark Plastic Corp., Akron, $\mathrm{OH}$ ). Containers were filled with premoistened commercial soilless peat-based substrate, comprised (by volume) $65 \%$ peat, $20 \%$ perlite, and $15 \%$ vermiculite, amended with dolomitic limestone, wetting agent, and a starter nutrient charge with gypsum (Fafard 2; Sun Gro Horticulture, Agawam, MA). Plants were irrigated to container capacity with water supplemented with $35 \%$ sulfuric acid (AutoCraft Battery Acid; Johnson Controls Battery Group, Milwaukee, WI) at $0.16 \mathrm{mg} \cdot \mathrm{L}^{-1}$ to neutralize alkalinity from 4.0 to $1.6 \mathrm{meq} \cdot \mathrm{L}^{-1}$ calcium carbonate and reduce $\mathrm{pH}$ from 7.3 to a range of 5.8 to 6.0 .

Plant fertility. Thirty-six plants per cultivar were placed on one of four greenhouse benches. Each bench was equipped with three independently controlled benchtop $1.9-\mathrm{cm}$ black irrigation lines fitted with 24, 12-cm diameter drip rings (Dramm USA, Manitowoc, WI) that were placed on top of the substrate of each container, corresponding to one of six fertilizer concentrations. Each of the six fertilizer concentrations was replicated twice for a total of 12 irrigation lines that were randomized in two blocks, each consisting of two benches. Irrigation lines were connected to sump pumps (model 1A; Little Giant Pump Co., Oklahoma City, OK) which delivered one of the six constant liquid fertilizer concentrations $(50,75,100,200$, 300 , or $400 \mathrm{mg} \cdot \mathrm{L}^{-1} \mathrm{~N}$ ) based on balanced ratios of $\mathrm{N}-\mathrm{P}-\mathrm{K}$ supplied by $15 \mathrm{~N}-1.7 \mathrm{P}-$ 12.5K (GreenCare Bordine's Special; Blackmore Co., Belleville, MI), containing 1.9\% ammoniacal $\left(\mathrm{NH}_{4}^{-}\right)-\mathrm{N}$ and $13.1 \%$ nitrate $\left(\mathrm{NO}_{3}{ }^{-}\right)-\mathrm{N}$. The fertilizer concentrations were selected based on grower practice and to determine minimum and maximum sufficiency ranges.

Regardless of fertilizer treatment, plants received a constant level of water-soluble micronutrient blend (GreenCare Bordine's Special; Blackmore Co.) supplying (in $\left.\mathrm{mg} \cdot \mathrm{L}^{-1}\right) 2.0 \mathrm{Fe}, 0.5 \mathrm{Mn}$ and $\mathrm{Zn}, 0.25 \mathrm{~B}$ and $\mathrm{Cu}$, and 0.1 molybdenum. The water-soluble fertilizer and micronutrient blend were weighed and dissolved together in 100-L fertilizer barrels. Plants were irrigated as needed to the point of leaching and were never allowed to dry out. Each month, plants received a $150-\mathrm{mL}$ drench containing 50 $\mathrm{mg} \cdot \mathrm{L}^{-1}$ magnesium sulfate $\left(\mathrm{MgSO}_{4} \cdot 7 \mathrm{H}_{2} \mathrm{O}\right)$. No solution was leached or drained from the containers after application.

Greenhouse environment. Plants were grown in a double polyethylene-covered greenhouse with roll up side curtains [MSU Tollgate Farm and Education Center, Novi, MI (lat. $\left.42^{\circ} \mathrm{N}\right)$ ], at $20{ }^{\circ} \mathrm{C}$, under ambient daylight supplemented with a photosynthetic photo flux density (PPFD) of $\approx 35.6$ $\mu \mathrm{mol} \cdot \mathrm{m}^{-2} \cdot \mathrm{s}^{-1}$, at plant height [as measured with a quantum sensor (LI-190SL; LI-COR Biosciences, Lincoln, NE)], delivered from $150 \mathrm{~W}$ high-pressure sodium (HPS) lamps (Sun System ${ }^{\circledR}$ HPS 150 Grow Light Fixture; Sunlight Supply, Inc., Vancouver, WA) from 0600 to 2200 HR (16-h photoperiod). On each bench, an enclosed thermocouple recorded air temperature every $30 \mathrm{~s}$ and averages were logged every $15 \mathrm{~min}$ by a data logger (WatchDog Model 2475 Plant Growth Station; Spectrum Technologies, Inc., Aurora, IL). Line quantum sensors (SQ-316-SS; Apogee Instruments, Inc., Logan, UT) mounted $60 \mathrm{~cm}$ above the benchtop measured PPFD every $30 \mathrm{~s}$ and the average of each sensor was logged every $15 \mathrm{~min}$ by a data logger (WatchDog 2800 Weather Station; Spectrum Technologies, Inc.). Average daily light integral, air temperature and relative humidity throughout the 8-week duration of the experiment were $12.3 \pm 4.7 \mathrm{~mol} \cdot \mathrm{m}^{-2} \cdot \mathrm{d}^{-1}, 22.7 \pm$ $2.2{ }^{\circ} \mathrm{C}$, and $64.8 \% \pm 6.2 \%$, respectively.

Growth and nutritional data and calculations. Data were collected on three randomly selected experimental units (individual plants) of each cultivar. Data were collected at 2, 4, 6, and 8 WAT. At each collection date, substrate solution was extracted $1 \mathrm{~h}$ after irrigation using the pourthrough method (Wright, 1986) and analyzed for $\mathrm{pH}$ and electrical conductivity (EC) using a HI 9813-6 portable meter (Hanna Instruments, Woonsocket, RI). Plant height was determined by measuring from the substrate surface to the apical meristem. Plant diameter was determined by measuring the widest dimension and the axis perpendicular to the widest dimension and averaging. Growth index [GI = (plant height + plant diameter $) /$ 2] was calculated for each plant. The PSC was determined by measuring below the lowest axillary shoot with a digital caliper (digiMax; Wiha, Schönach, Germany).

At 2, 4, 6, and 8 WAT, the recently mature (youngest fully expanded) leaves were removed from the selected three experimental units from each cultivar. Leaves were washed in a solution of $0.5 \mathrm{~N}$ hydrochloric acid for $1 \mathrm{~min}$ and rinsed in deionized water before being individually bagged, and was dried in an oven at $70{ }^{\circ} \mathrm{C}$ for 1 week. After 1 week, dried tissue was weighed to determine young leaf dry mass (YDM) and ground with a mortar and pestle to pass a $\leq 0.5-\mathrm{mm}$ sieve, placed in $15-\mathrm{mL}$ polypropylene conical centrifuge tubes (Falcon $17 \times 120 \mathrm{~mm}$; Corning, Corning, NY), and analyzed for nutrient concentrations by AgSource Laboratories (Lincoln, NE). Total $\mathrm{N}$ was processed by Kjeldahl digestion and determined by flow injection analysis. Extractable $\mathrm{K}$ was processed by $2 \%$ acetic acid digestion and determined by inductively coupled plasma mass spectrometry (ICP-MS). Total $\mathrm{P}$ and all other plant minerals $(\mathrm{Ca}, \mathrm{Mg}, \mathrm{Fe}, \mathrm{Mn}, \mathrm{Zn}$, $\mathrm{B}, \mathrm{Cu}$, and $\mathrm{Al}$ ) were processed by nitric acid/ hydrogen peroxide digestion, and determined by ICP-MS.

The remaining plant tissues were destructively harvested by severing the stem at the substrate surface, individually bagging and drying in an oven at $70{ }^{\circ} \mathrm{C}$. After 1 week, plant dry mass (PDM) was determined. Total plant dry mass [TDM; $($ TDM $=$ YDM + PDM)] was calculated for each plant.

Experimental design and statistical analyses. The experiment was laid out in a randomized complete block design with two blocks and six fertilizer concentrations arranged in a split-plot with two replicates within each split-plot. Cultivars were randomized within each replicate. There were three experimental units per cultivar per fertilizer concentrations per replicate. Within each block, no significant differences occurred among replicates per cultivar; therefore, data were pooled. The effects of fertilizer concentrations per cultivar were analyzed using SAS (version 9.2; SAS Institute, Cary, NC) general linear model procedure (PROC GLM) for analysis of variance, and means were separated between fertilizer concentrations using Tukey's honestly significant differences. For each cultivar, regression analyses of foliar nutrient concentrations within WAT with fertilizer concentration as the independent variable were performed using SAS regression procedure (PROC REG). Regression models, equations, and adjusted- $R^{2}$ are provided in Table 1 . For all analyses, a $P \leq 0.05$ was used to determine significant effects.

\section{Results and Discussion}

Sufficiency range. At 8 WAT, increasing fertilizer concentrations significantly influenced plant height, diameter, GI, PSC, and TDM of both Hibiscus cultivars (Table 2; Figs. 1 and 2). Plant growth was analyzed to determine lower and upper optimal nutritional limits. The Hibiscus plants fertilized with 50 and $75 \mathrm{mg} \cdot \mathrm{L}^{-1} \mathrm{~N}$ resulted in similar and significantly smaller plant height, diameter, GI, PSC, and TDM than those fertilized with $100-400 \mathrm{mg} \cdot \mathrm{L}^{-1} \mathrm{~N}$. Therefore, $100 \mathrm{mg} \cdot \mathrm{L}^{-1} \mathrm{~N}$ was determined as the lower 
nutritional limit, and the plants fertilized with 50 and $75 \mathrm{mg} \cdot \mathrm{L}^{-1} \mathrm{~N}$ were excluded from further statistical analyses.

Plant growth of both Hibiscus cultivars was statistically similar among ascending fertilizer concentration from 100 to 400 $\mathrm{mg} \cdot \mathrm{L}^{-1} \mathrm{~N}$ (Table 2). However, TDM of 'Mocha Moon' and 'Starry Starry Night' at increasing fertilizer concentrations of 300 $400 \mathrm{mg} \cdot \mathrm{L}^{-1} \mathrm{~N}$ decreased by $12.5 \%$ (4.6 g) and $11.8 \%(4.2 \mathrm{~g})$, respectively. Smaller TDM is most likely attributed to sensitivity of an elevated substrate EC (Scoggins, 2005). For instance, average substrate EC extracted from 'Mocha Moon' and 'Starry Starry Night' grown at $400 \mathrm{mg} \cdot \mathrm{L}^{-1} \mathrm{~N}$ were 4.22 and $4.50 \mathrm{mS} \cdot \mathrm{cm}^{-1}$, respectively, and they were $30 \%$ to $929 \%\left(0.97-3.81 \mathrm{mS} \cdot \mathrm{cm}^{-1}\right)$ and $32 \%$ to $1084 \%\left(1.08-4.12 \mathrm{mS} \cdot \mathrm{cm}^{-1}\right)$ higher than the average substrate EC values determined for plants fertilized at 50-300 $\mathrm{mg} \cdot \mathrm{L}^{-1} \mathrm{~N}$, respectively. Furthermore, drawing from experience of common grower practices, fertilizer costs, and possible environmental impacts of excessive fertilization, it was concluded that plants fertilized with $\geq 300 \mathrm{mg} \cdot \mathrm{L}^{-1} \mathrm{~N}$ would be entering a situation of luxury nutrient consumption and the additional fertilizer was not beneficial to plant quality (Jeong et al., 2009; Krug et al., 2010; Papineau and Krug, 2014). When TDM and substrate EC data are taken together, $300 \mathrm{mg} \cdot \mathrm{L}^{-1} \mathrm{~N}$ was determined as the upper nutritional range limit, and plants fertilized with $400 \mathrm{mg} \cdot \mathrm{L}^{-1} \mathrm{~N}$ were excluded from further statistical analyses. Thus, the optimal sufficiency range for both Hibiscus cultivars in this study is 100 $300 \mathrm{mg} \cdot \mathrm{L}^{-1} \mathrm{~N}$.

Table 1. Regression models, equation, and adjusted- $R^{2}$ for sufficiency ranges of macronutrients [nitrogen $(\mathrm{N})$, phosphorus $(\mathrm{P})$, potassium $(\mathrm{K})$, calcium $(\mathrm{Ca})$, magnesium $(\mathrm{Mg})$, and sulfur $(\mathrm{S})$ ] and micronutrients [iron ( $\mathrm{Fe})$, manganese $(\mathrm{Mn})$, zinc $(\mathrm{Zn})$, copper $(\mathrm{Cu})$, boron $(\mathrm{B})$, and aluminum $(\mathrm{Al})$ ] over an 8-week crop cycle in two hibiscus (Hibiscus hybrid L. 'Mocha Moon' and 'Starry Starry Night') cultivars grown at 100-300 mg.L ${ }^{-1}$ N. Data were pooled over cultivars.

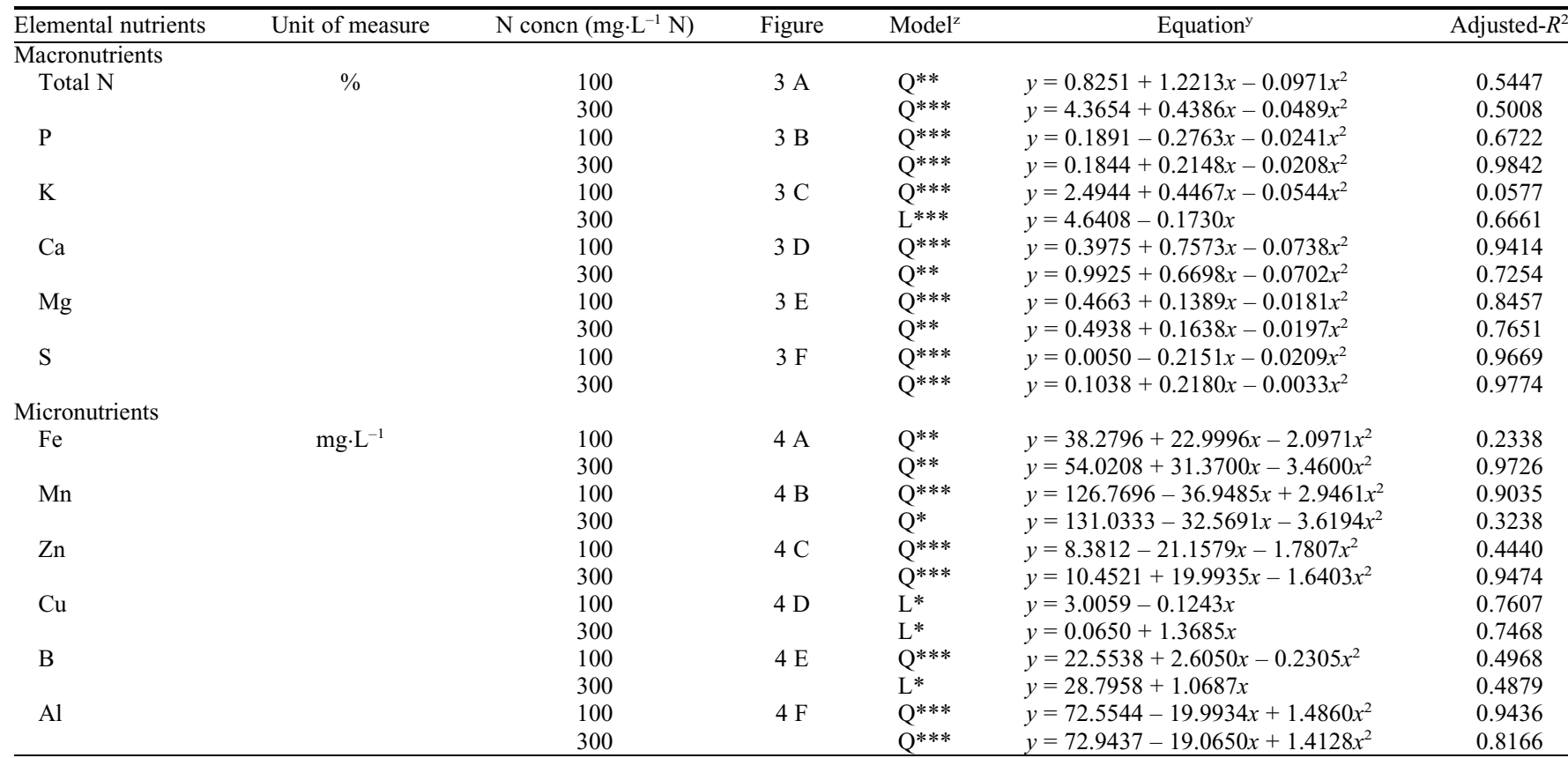

${ }^{\mathrm{z}}$ Linear $(\mathrm{L})$ or quadratic $(\mathrm{Q})$ response for $\mathrm{N}$ concentration.

${ }^{\mathrm{y}} \mathrm{L}(y=a x+b)$ or $\mathrm{Q}\left(y=a x^{2}+b x+c\right)$ equations for concentration.

Ns, $,{ }^{* * *}, * * *$ Nonsignificant or significant at $P \leq 0.05,0.01$, or 0.001 .

Table 2. Average plant height, diameter, growth indices (GI), primary shoot caliper (PSC), and total plant dry mass (TDM) of two hibiscus (Hibiscus hybrid L. 'Mocha Moon' and 'Starry Starry Night') cultivars grown at six fertilizer concentrations, harvested at 8 weeks after transplant.

\begin{tabular}{|c|c|c|c|c|c|}
\hline Nitrogen $(\mathrm{N})$ concn $\left(\mathrm{mg} \cdot \mathrm{L}^{-1} \mathrm{~N}\right)$ & $\mathrm{Ht}^{\mathrm{z}}(\mathrm{cm})$ & $\operatorname{Diam}^{y}(\mathrm{~cm})$ & $\mathrm{GI}^{\mathrm{x}}(\mathrm{cm})$ & $\mathrm{PSC}^{\mathrm{w}}(\mathrm{mm})$ & $\mathrm{TDM}^{\mathrm{v}}(\mathrm{g})$ \\
\hline \multicolumn{6}{|l|}{ 'Mocha Moon' } \\
\hline 50 & $41.9 b^{u}$ & $43.0 \mathrm{~b}$ & $74.3 \mathrm{c}$ & $13.0 \mathrm{c}$ & $22.1 \mathrm{c}$ \\
\hline 75 & $54.6 \mathrm{ab}$ & $45.9 \mathrm{ab}$ & $88.9 \mathrm{bc}$ & $15.4 \mathrm{bc}$ & $27.8 \mathrm{bc}$ \\
\hline 100 & $61.0 \mathrm{a}$ & $47.1 \mathrm{a}$ & $96.9 \mathrm{ab}$ & $18.3 \mathrm{ab}$ & $31.5 \mathrm{ab}$ \\
\hline 200 & $67.3 \mathrm{a}$ & $52.6 \mathrm{a}$ & $106.6 \mathrm{a}$ & $18.9 \mathrm{a}$ & $34.6 \mathrm{a}$ \\
\hline 300 & $71.1 \mathrm{a}$ & $51.3 \mathrm{a}$ & $109.6 \mathrm{a}$ & $18.2 \mathrm{ab}$ & $36.8 \mathrm{a}$ \\
\hline 400 & $70.4 \mathrm{a}$ & $51.9 \mathrm{a}$ & $108.9 \mathrm{a}$ & $18.1 \mathrm{ab}$ & $32.2 \mathrm{~b}$ \\
\hline Significance & $* * *$ & $* *$ & $* * *$ & $* * *$ & $* * *$ \\
\hline \multicolumn{6}{|l|}{ 'Starry Starry Night' } \\
\hline 50 & $29.9 \mathrm{~d}$ & $33.1 \mathrm{c}$ & $54.6 \mathrm{c}$ & $10.5 \mathrm{~d}$ & $16.4 \mathrm{c}$ \\
\hline 75 & $43.6 \mathrm{~d}$ & $39.0 \mathrm{abc}$ & $72.8 \mathrm{~b}$ & $14.8 \mathrm{c}$ & $22.5 \mathrm{~b}$ \\
\hline 100 & $59.5 \mathrm{a}$ & $45.7 \mathrm{a}$ & $85.7 \mathrm{a}$ & $18.9 \mathrm{a}$ & $26.8 \mathrm{ab}$ \\
\hline 200 & $61.8 \mathrm{a}$ & $46.1 \mathrm{a}$ & $97.4 \mathrm{a}$ & $19.3 \mathrm{a}$ & $32.3 \mathrm{a}$ \\
\hline 300 & $63.8 \mathrm{a}$ & $42.7 \mathrm{abc}$ & $96.1 \mathrm{a}$ & $17.3 \mathrm{~b}$ & $35.6 \mathrm{a}$ \\
\hline 400 & $63.4 \mathrm{a}$ & $36.2 \mathrm{c}$ & $90.4 \mathrm{a}$ & $17.5 \mathrm{~b}$ & $31.4 \mathrm{~b}$ \\
\hline Significance & $* * *$ & $* *$ & $* * *$ & $* * *$ & $* * *$ \\
\hline
\end{tabular}

${ }^{\mathrm{z}}$ Plant height measured from the substrate surface to the apical meristem.

${ }^{\mathrm{y}}$ Plant diameter determined by measuring the widest dimension and the axis perpendicular to the widest dimension and averaged.

${ }^{\mathrm{x}} \mathrm{GI}=$ (plant height + plant diameter $\left.) / 2\right]$.

${ }^{\mathrm{w}} \mathrm{PSC}$ determined by measuring below the lowest axillary shoot.

${ }^{\mathrm{v}} \mathrm{TDM}=$ young plant dry mass + plant dry mass.

${ }^{\text {u} W i t h i n-c o l u m n ~ m e a n s ~}(\mathrm{n}=3)$ followed by different lower-case letters are significantly different by Tukey's honestly significant differences test at $P \leq 0.05$.

Ns, *, **, *** Nonsignificant or significant at $P \leq 0.05,0.01$, or 0.001 , respectively. 


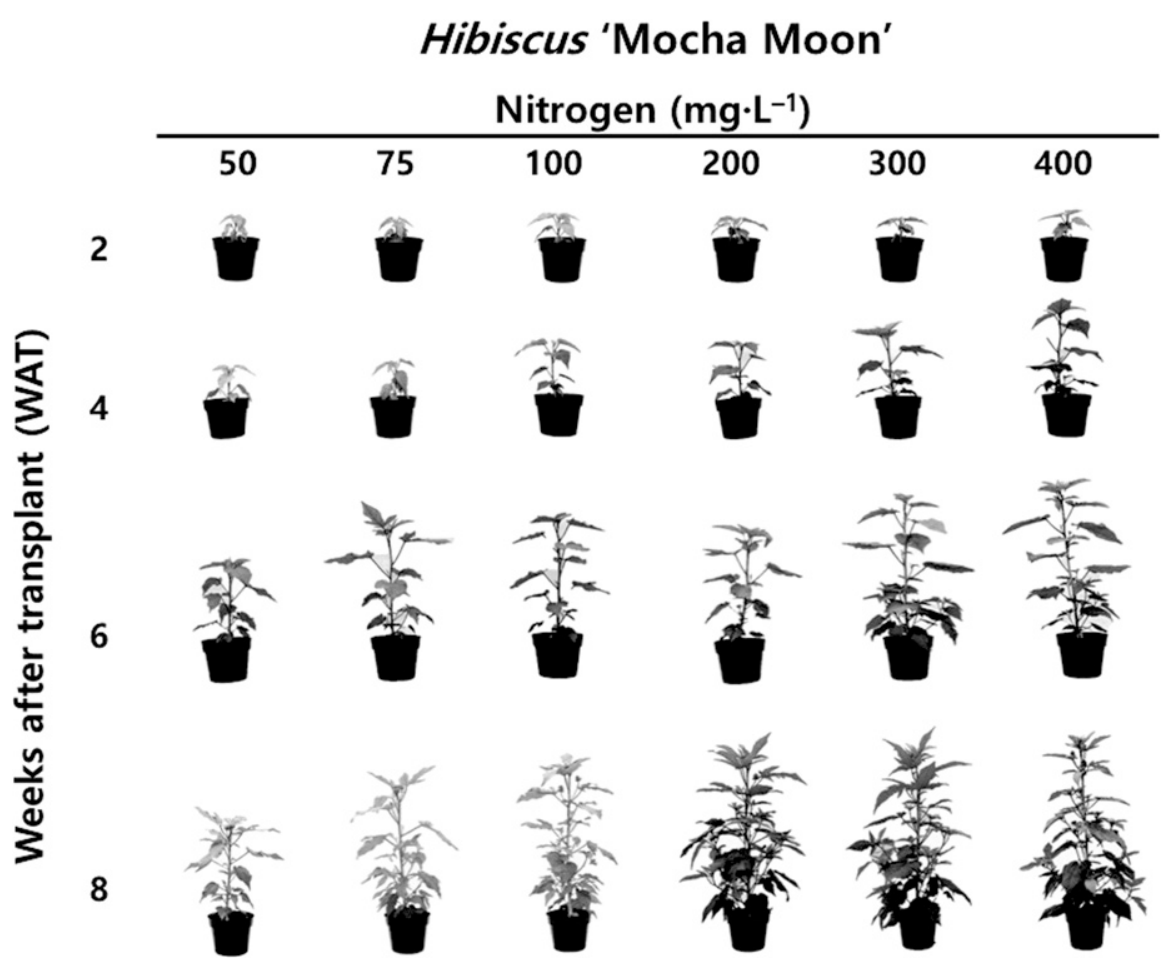

Fig. 1. Depiction of hibiscus (Hibiscus hybrid L. 'Mocha Moon') fertilized with one of six constant liquid fertilizer concentrations $\left[50,75,100,200,300\right.$, or $400 \mathrm{mg} \cdot \mathrm{L}^{-1}$ nitrogen (N)] based on balanced ratios of N-phosphorouspotassium and a constant level of water-soluble micronutrient blend at 2, 4, 6, and 8 weeks after transplant.

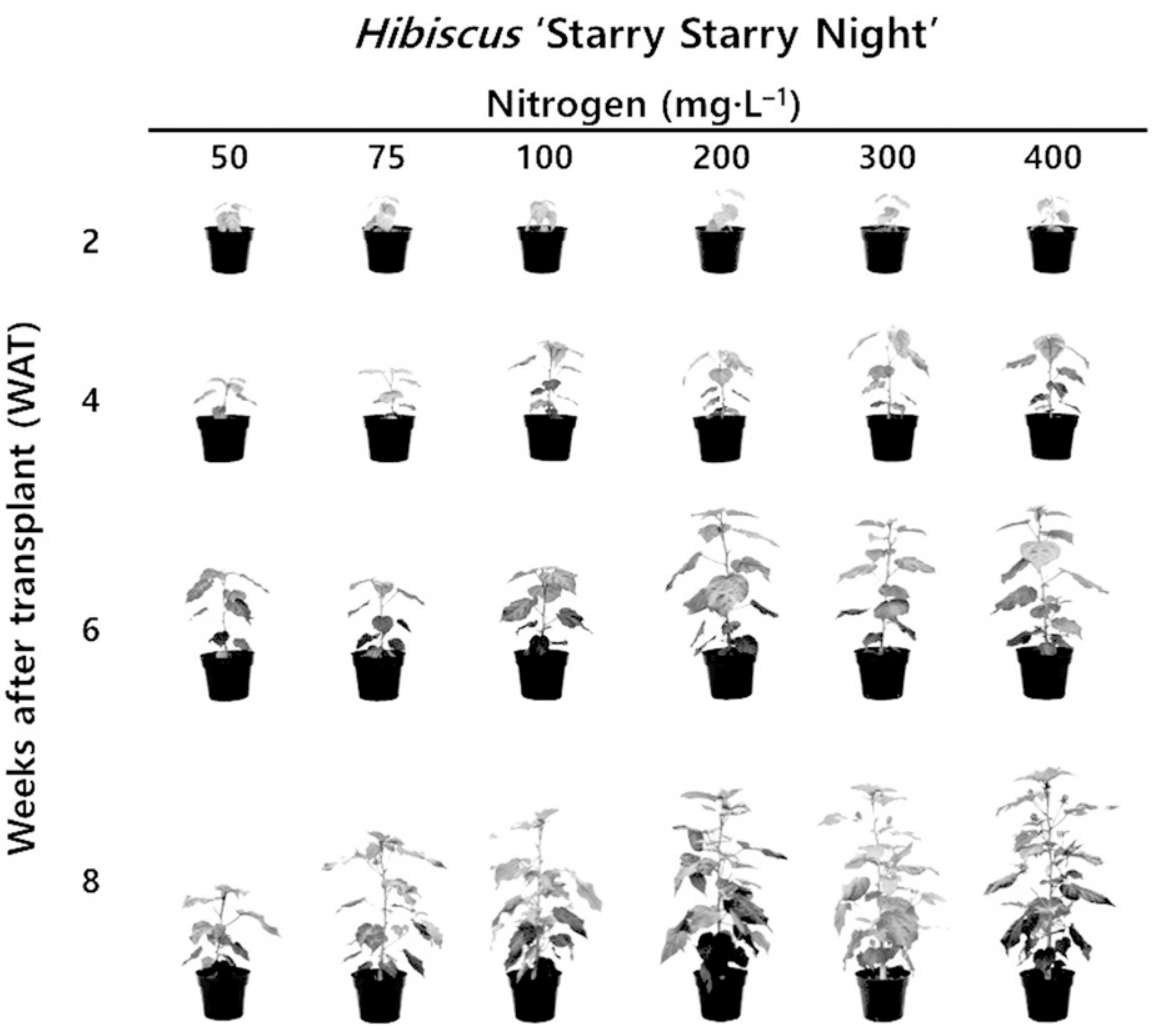

Fig. 2. Depiction of hibiscus (Hibiscus hybrid L. 'Starry Starry Night') fertilized with one of six constant liquid fertilizer concentrations $\left[50,75,100,200,300\right.$, or $400 \mathrm{mg} \cdot \mathrm{L}^{-1}$ nitrogen $\left.(\mathrm{N})\right]$ based on balanced ratios of $\mathrm{N}$-phosphorous-potassium and a constant level of water-soluble micronutrient blend at 2, 4, 6 , and 8 weeks after transplant.

Sufficiency ranges for both Hibiscus cultivars were used to determine recommend leaf tissue concentrations of 12 elements by chronological age. Similar to Papineau and Krug (2014), lower and upper limits of recommended leaf tissue concentration ranges were defined as the best fit regressions of the pooled data from all Hibiscus plants grown at 100-300 $\mathrm{mg} \cdot \mathrm{L}^{-1} \mathrm{~N}$ over an 8-week crop cycle. The nutrient concentrations differed between 'Mocha Moon' and 'Starry Starry Night', but the means were within the established range for each elemental nutrient. To date, no leaf tissue concentration limits are published for $H$. hybrid, but survey measurements taken from greenhouse- and nursery-grown Chinese hibiscus (Hibiscus rosa-sinensis L.) and rose of Sharon (Hibiscus syriacus L. 'Aphrodite', 'Blue Bird', 'Blushing Bride', 'Collie Mullens', 'Diana', 'Helene', and 'Red Heart') are reported by Bryson and Mills (2014). These tissue concentration ranges will be referred to as the genera Hibiscus.

Nitrogen. Total $\mathrm{N}\left(\mathrm{NO}_{3}{ }^{-}\right.$and $\left.\mathrm{NH}_{4}^{-}\right)$concentration of Hibiscus cultivars in this study harvested at 2, 4, 6, and 8 WAT (Table 3; Fig. 3A) were within a narrower sufficiency range than those previously reported $(2.50 \%$ to $4.56 \% \mathrm{~N}$; Bryson and Mills, 2014). At all stages of growth, total $\mathrm{N}$ tissue concentration was higher in the plants fertilized with 300 $\mathrm{mg} \cdot \mathrm{L}^{-1} \mathrm{~N}$ than those fertilized with 100 mg. $\mathrm{L}^{-1} \mathrm{~N}$ (Fig. 3A). At 2 WAT, total $\mathrm{N}$ tissue concentration ranged from $3.1 \%$ to $5.1 \%$ and increased to $5.2 \%$ to $5.4 \%$ at 6 WAT. These results are consistent with Jeong et al. (2009) which reported increased leaf tissue $\mathrm{N}$ concentration of gerbera when fertilized with 100-200 $\mathrm{mg} \cdot \mathrm{L}^{-1} \mathrm{~N}$ from transplant until first open flower (2-8 WAT). Total $\mathrm{N}$ tissue concentration of Hibiscus decreased to $4.2 \%$ to $4.7 \%$ at 8 WAT when floral buds were visible. This is similar to Krug et al. (2010) which observed decreased leaf tissue $\mathrm{N}$ concentration of flowering zonal geranium 'Tango Dark Red' and 'Rocky Mountain Dark Red' plants fertilized with 100-300 $\mathrm{mg} \cdot \mathrm{L}^{-1} \mathrm{~N}$ at $12 \mathrm{WAT}$.

Phosphorus. The recommended range for leaf tissue $\mathrm{P}$ concentration for the genera Hibiscus is between $0.2 \%$ and $1.0 \%$ (Bryson and Mills, 2014). Leaf tissue P concentration of the Hibiscus cultivars in this study is consistent with those previously published. The overall lower and upper limit range increased in a quadratic fashion over time (Fig. 3B), and this trend was also observed in gerbera (Jeong et al., 2009). For plants fertilized with $100 \mathrm{mg} \cdot \mathrm{L}^{-1} \mathrm{~N}$, lower optimal $\mathrm{P}$ concentrations were $0.30 \%$ to $0.45 \% \mathrm{P}$ at 2 (young growth) to 8 WAT (visible bud), respectively (Table 3; Fig. 3B). For plants fertilized with $300 \mathrm{mg} \cdot \mathrm{L}^{-1} \mathrm{~N}, \mathrm{P}$ concentrations increased from $0.53 \%$ to $0.73 \% \mathrm{P}$ from 2 to 6 WAT, respectively, and then decreased to $0.57 \% \mathrm{P}$ at visible bud (Table 3 ; Fig. $3 \mathrm{~B}$ ). At all stages of the crop cycle, $\mathrm{P}$ tissue concentration were higher in plants grown at $300 \mathrm{mg} \cdot \mathrm{L}^{-1} \mathrm{~N}$ than $100 \mathrm{mg} \cdot \mathrm{L}^{-1} \mathrm{~N}$ and within a narrower range than recommended published ranges by Bryson and Mills (2014).

Potassium. The recommended range for leaf tissue $\mathrm{K}$ concentration for the genera Hibiscus is between $1.21 \%$ and $3.35 \%$ (Bryson and Mills, 2014). When plants were fertilized with $100 \mathrm{mg} \cdot \mathrm{L}^{-1} \mathrm{~N}$, a quadratic 
Table 3. Sufficiency ranges of 12 elemental nutrients determined at 2 (young growth), 4 (active growth), 6 (mature growth), and 8 (visible bud) weeks after transplant (WAT) for two hibiscus (Hibiscus hybrid L. 'Mocha Moon' and 'Starry Starry Night') cultivars $(\mathrm{n}=3)$ grown with $100-300$ mg. ${ }^{-1}$ nitrogen $(\mathrm{N})$ and recommended leaf tissue for the genera Hibiscus as previously published by Bryson and Mills (2014).

\begin{tabular}{|c|c|c|c|c|c|c|}
\hline \multirow[b]{2}{*}{ Elemental nutrients } & \multirow[b]{2}{*}{ Unit of measure } & \multicolumn{4}{|c|}{ WAT } & \multirow{2}{*}{$\frac{\text { Hibiscus }}{\text { Bryson and Mills }(2014)^{z}}$} \\
\hline & & $\overline{2 \text { (Young growth) }}$ & 4 (Active growth) & 6 (Mature growth) & 8 (Visible bud) & \\
\hline \multicolumn{7}{|l|}{ Macronutrients } \\
\hline Total N & $\%$ & $3.08-5.11$ & $3.59-5.15$ & $5.25-5.42$ & $4.20-4.68$ & $2.50-4.56$ \\
\hline Phosphorus & & $0.30-0.53$ & $0.44-0.70$ & $0.69-0.73$ & $0.45-0.57$ & $0.20-1.00$ \\
\hline Potassium & & $3.17-4.08$ & $3.43-4.15$ & $3.20-3.86$ & $3.02-2.59$ & $1.21-3.35$ \\
\hline Calcium & & $1.60-2.01$ & $2.30-2.67$ & $2.23-2.36$ & $1.76-1.90$ & $1.00-5.18$ \\
\hline Magnesium & & $0.66-0.76$ & $0.77-0.79$ & $0.61-0.81$ & $0.43-0.53$ & $0.25-1.12$ \\
\hline Sulfur & & $0.34-0.45$ & $0.53-0.65$ & $0.52-0.61$ & $0.46-0.38$ & $0.20-0.50$ \\
\hline \multicolumn{7}{|l|}{ Micronutrients } \\
\hline Iron & $\mathrm{mg} \cdot \mathrm{L}^{-1}$ & $79.2-103.5$ & $82.9-122.1$ & $107.6-119.7$ & $75.6-82.9$ & $50-200$ \\
\hline Manganese & & $66.3-82.8$ & $21.1-51.4$ & $16.2-73.1$ & $18.1-99.7$ & $40-289$ \\
\hline Zinc & & $29.0-43.3$ & $41.1-66.0$ & $61.1-69.5$ & $44.7-45.7$ & $20-200$ \\
\hline Copper & & $2.5-3.3$ & $3.3-3.8$ & $6.7-10.2$ & $5.9-10.3$ & $6-50$ \\
\hline Boron & & $27.5-29.8$ & $27.5-29.1$ & $31.7-34.4$ & $28.0-35.6$ & $25-114$ \\
\hline Aluminum & & $39.3-41.8$ & $13.9-15.0$ & $6.9-8.5$ & $9.4-13.7$ & $\ldots$ \\
\hline
\end{tabular}

${ }^{\mathrm{z}}$ Recommended leaf tissue range for the genera Hibiscus previously published by Bryson and Mills (2014).

${ }^{\mathrm{y}}$ No previously reported recommended leaf tissue range for the genera Hibiscus by Bryson and Mills (2014).

response was observed where an increase in $\mathrm{K}$ concentration occurred between 2 and 4 WAT (young to active growth), and decreased over time from 6 to 8 WAT (maturity to visible bud) (Table 3; Fig. 1C). At 300 $\mathrm{mg} \cdot \mathrm{L}^{-1} \mathrm{~N}, \mathrm{~K}$ concentration decreased linearly from $4.08 \%$ to $2.59 \% \mathrm{~K}$ at $2-8 \mathrm{WAT}$, respectively (Table 3; Fig. 3C). However, the upper range limit was $21.7 \%, 23.8 \%$, and $15.2 \%$ higher at 2,4 , and 6 WAT than the limit reported by Bryson and Mills (2014), thus broadening the recommended range of leaf tissue $\mathrm{K}$ concentration.

Calcium. The recommended range for leaf tissue $\mathrm{Ca}$ concentration for the genera Hibiscus is between $1.0 \%$ and $5.18 \%$ (Bryson and Mills, 2014). The previously published $\mathrm{Ca}$ concentration range for Hibiscus is broader than observed for the cultivars in this study (Table 3). In general, upper and lower $\mathrm{Ca}$ leaf concentration range limits followed a quadratic response (Fig. 3D). The measured $\mathrm{Ca}$ tissue concentrations were $1.60 \%$ to $2.01 \% \mathrm{Ca}$ at $2 \mathrm{WAT}$ (young growth), increased to $2.30 \%$ to $2.67 \% \mathrm{Ca}$ at 4 WAT (active growth), and then decreased as the plants matured from 6 to 8 WAT. The observed trend is consistent with zonal geranium 'Rocky Mountain Dark Red' (Krug et al., 2010), but not osteospermum (Papineau and Krug, 2014) or gerbera (Jeong et al., 2009). Calcium concentration should increase as plants mature (Krug et al., 2010). However, the observed decrease in Ca concentration from 6 to 8 WAT (maturity to visible bud) may be attributed to competitive uptake of $\mathrm{K}$ or high relative humidity in the greenhouse thus limiting $\mathrm{Ca}$ movement to meristematic tissues (Bryson and Mills, 2014), although no Ca deficiency symptoms were observed. Furthermore, substrate $\mathrm{pH}$ ranged from 5.8 to 6.5 which is optimal for Hibiscus production and within the optimal range for $\mathrm{Ca}$ availability (Dole and Wilkins, 2005).

Magnesium. The recommended range for leaf tissue $\mathrm{Mg}$ concentration for the genera Hibiscus is between $0.25 \%$ and $1.12 \%$ (Bryson and Mills, 2014). Similar to $\mathrm{Ca}$, the previously published $\mathrm{Mg}$ concentration range for Hibiscus is broader than observed for the cultivars in this study (Table 3 ). In general, a quadratic response was observed (Fig. 2E). For the lower range limit, tissue $\mathrm{Mg}$ concentration increased by $17 \%$ from 2 to 4 WAT (young to active growth) and then decreased as the plants matured from 6 WAT onward (Fig. 2E). The upper limit increased steadily from $0.76 \%$ to $0.81 \% \mathrm{Mg}$ from 2 to $6 \mathrm{WAT}$ (young to maturity) and then decreased at 8 WAT $(0.53 \% \mathrm{Mg})$. Krug et al. (2010) reported a similar trend for the upper range limit of geranium 'Rocky Mountain Dark Red' from 2 to 12 WAT. Although within the recommended range, $\mathrm{Mg}$ concentrations were significantly lower at 8 WAT and may be attributed to the antagonistic effect of $\mathrm{K}$ from the fertilizer source, reduced residual effect of the dolomitic limestone used to adjust substrate $\mathrm{pH}$, or a dilution effect of dry mass and a consistent volume of $\mathrm{MgSO}_{4}$ applied.

Sulfur. The recommended range for leaf tissue S concentration for the genera Hibiscus is between $0.2 \%$ and $0.5 \%$ (Bryson and Mills, 2014). Lower and upper limits for the Hibiscus cultivars in this study followed a quadratic response over time (Fig. 3F), and were similar to gerbera (Jeong et al., 2009). The sulfur concentrations at 4 and 6 WAT (active growth and maturity) were $0.53 \%$ to $0.65 \%$ and $0.52 \%$ to $0.61 \% \mathrm{~S}$ (Table 3 ; Fig. $3 \mathrm{~F}$ ), respectively, which were greater than the ranges previously published by Bryson and Mills (2014), thus indicating a broader range limit.

Iron. The recommended range for leaf Fe concentration for the genera Hibiscus is between 50 and $200 \mathrm{mg} \cdot \mathrm{L}^{-1}$ (Bryson and Mills, 2014). In general, a quadratic response was observed where $\mathrm{Fe}$ concentration at lower and upper limits increased from 2 to $4 \mathrm{WAT}$ and then decreased at $6 \mathrm{WAT}$ onward (Table 3; Fig. 3A). The Fe concentrations were lower and within a narrower range than those published by Bryson and Mills (2014) and ranged from 79.2 to $103.6,82.9$ to 122.1 , 107.6 to 119.7 , and 75.6 to $82.9 \mathrm{mg} \cdot \mathrm{L}^{-1} \mathrm{Fe}$ at $2,4,6$, and 8 WAT, respectively. The observed lower range may likely be attributed to the constant rate of micronutrients supplied at each fertilizer concentration and not related to Fe deficiency which is associated with substrate $\mathrm{pH}>6.5$ because no deficiency symptoms were observed.

Manganese. The recommended range for Mn concentration for the genera Hibiscus is between 40 and $289 \mathrm{mg} \cdot \mathrm{L}^{-1} \mathrm{Mn}$ (Bryson and Mills, 2014). In the present study, Mn concentration decreased quadratically when plants were fertilized with 100 and 300 $\mathrm{mg} \cdot \mathrm{L}^{-1} \mathrm{~N}$, but was higher for plants fertilized with 300 than $100 \mathrm{mg} \cdot \mathrm{L}^{-1} \mathrm{~N}$ (Fig. 4B). Manganese concentrations for plants grown with $100 \mathrm{mg} \cdot \mathrm{L}^{-1} \mathrm{~N}$ declined from 66.3 to 18.1 $\mathrm{mg} \cdot \mathrm{L}^{-1} \mathrm{Mn}$ beginning at $2-8 \mathrm{WAT}$, respectively (Table 3 ). These values are lower than those previously published (Bryson and Mills, 2014) and plant tissue would be considered Mn deficient. Although Mn concentrations were narrower than previously published ranges, visual symptomology was not observed in either Hibiscus cultivars. Increased substrate $\mathrm{pH}$ may attribute to the suppressive effect on plant Mn uptake and content or the antagonistic effect of $\mathrm{Fe}$ competing for absorption (Bryson and Mills, 2014). The upper optimal ranges for plants grown with $300 \mathrm{mg} \cdot \mathrm{L}^{-1} \mathrm{~N}$ increased by $20 \%$ $\left(16.9 \mathrm{mg} \cdot \mathrm{L}^{-1} \mathrm{Mn}\right)$ at $2-8 \mathrm{WAT}$. Although the Mn concentration were within a narrower range than previously published ranges, the range became broader as the plants matured (Fig. 4B). This is consistent with trends reported for geranium 'Tango Dark Red' (Krug et al. 2010), gerbera (Jeong et al., 2009), and osteospermum cultivars (Papineau and Krug, 2014).

Zinc. The recommended range for $\mathrm{Zn}$ concentration for the genera Hibiscus is between 20 and $200 \mathrm{mg} \cdot \mathrm{L}^{-1} \mathrm{Zn}$ (Bryson and Mills, 2014). Zinc tissue concentrations in the present study were lower and within a narrower range that those previously published for the genera Hibiscus. Lower and upper limits followed a quadratic response over time (Fig. 4C), similar to gerbera (Jeong 


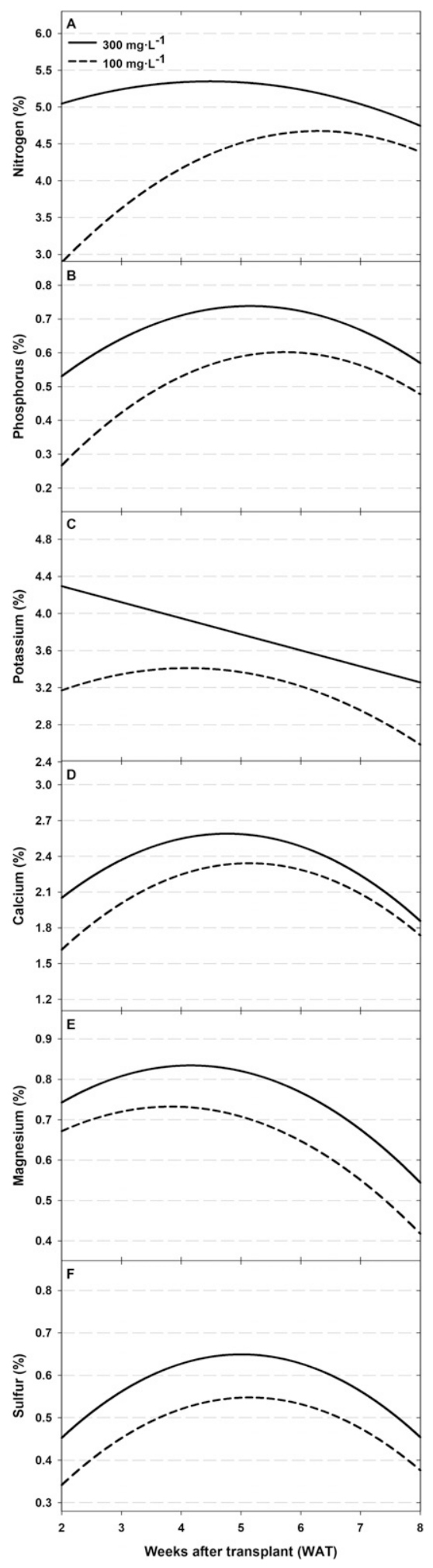

Fig. 3. Sufficiency ranges of macronutrients [nitrogen $(\mathrm{N})$, phosphorus, potassium, calcium, magnesium, and sulfur] over an 8-week crop cycle in two hibiscus (Hibiscus hybrid L. 'Mocha Moon' and 'Starry Starry Night') cultivars grown at $100-300 \mathrm{mg} \cdot \mathrm{L}^{-1} \mathrm{~N}$. Measured as the mean \pm SD. Data were pooled over cultivars.

et al., 2009) and osteospermum cultivars (Papineau and Krug, 2014). The lower and upper range limits for $\mathrm{Zn}$ tissue concentration increased from 29.0 to 61.1 and 43.3 to 69.5

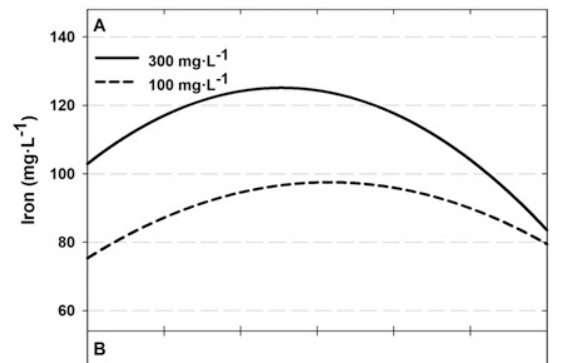

tions observed at 8 WAT may be the result of limited diffusion of available $\mathrm{Zn}$ for uptake because of extensive root growth and development. However, uptake earlier in the crop cycle (at 4-6 WAT) was not limited. Furthermore, Bryson and Mills (2014) indicated that high levels of available $\mathrm{P}$ and Fe in soils also adversely affects plant uptake of $\mathrm{Zn}$, which may attribute to lower concentrations observed at 8 WAT.

Copper. The recommended range for $\mathrm{Cu}$ concentration for the genera Hibiscus is between 6 and $50 \mathrm{mg} \cdot \mathrm{L}^{-1} \mathrm{Cu}$ (Bryson and Mills, 2014). Over time, $\mathrm{Cu}$ tissue concentration increased linearly (Fig. 4D). Copper concentrations of plants fertilized with 100$300 \mathrm{mg} \cdot \mathrm{L}^{-1} \mathrm{~N}$ were $2.5-3.3$ and $3.3-3.8$ $\mathrm{mg} \cdot \mathrm{L}^{-1} \mathrm{Cu}$ at 2-4 WAT (Table 3), respectively, and were lower than those previously published for the genera Hibiscus. However, $\mathrm{Cu}$ deficiency is uncommon in greenhouse production (Jeong et al., 2009) and no deficiency symptoms were observed. Copper deficient plant tissue may be attributed to the dilution effect caused by plant growth following $\mathrm{N}$ fertilization (Bryson and Mills, 2014), although average GI of plants fertilized with $100-300 \mathrm{mg} \cdot \mathrm{L}^{-1} \mathrm{~N}$ at 2 and 4 WAT were 15.7-16.9 and 24.4-29.4 cm, respectively, and not statistically different (data not shown).

Boron. The recommended range for $\mathrm{B}$ concentration for the genera Hibiscus is between 25 and $114 \mathrm{mg} \cdot \mathrm{L}^{-1}$ B (Bryson and Mills, 2014). When plants were fertilized with $100 \mathrm{mg} \cdot \mathrm{L}^{-1} \mathrm{~N}$, a quadratic response was observed where a slight increase in B concentration occurred from 2 to 6 WAT (young to maturity), and decreased at $8 \mathrm{WAT}$ (visible bud) (Table 3; Fig. 4E). At 300 $\mathrm{mg} \cdot \mathrm{L}^{-1} \mathrm{~N}, \mathrm{~B}$ concentration increased linearly from $29.8 \%$ to $35.6 \% \mathrm{mg} \cdot \mathrm{L}^{-1} \mathrm{~B}$ at $2-8 \mathrm{WAT}$, respectively (Table 3; Fig. 4E). Boron tissue concentrations in this study provide a narrower range limit than values reported by Bryson and Mills (2014).

Aluminum. To date, no recommended range for $\mathrm{Al}$ concentration for the genera Hibiscus exists over time. The present study establishes an optimal concentration range overtime where tissue concentration decreased in a quadratic fashion (Fig. 4F). Aluminum concentrations of plants fertilized with $100-300 \mathrm{mg} \cdot \mathrm{L}^{-1} \mathrm{~N}$ were $39.3-41.8$ $\mathrm{mg} \cdot \mathrm{L}^{-1}$ at 2 WAT and decreased to $9.4-13.7$ $\mathrm{mg} \cdot \mathrm{L}^{-1}$ at $8 \mathrm{WAT}$ (Table 3 ). Although not an essential element (Bryson and Mills, 2014), Morgan (2000) describes Al as a new beneficial element for plants which may influence root activity for $\mathrm{P}$ uptake. Based on these findings and the statement by Morgan (2000), it is postulated that the observed decreasing $\mathrm{Al}$ concentrations from 2 to 8 WAT may contribute to increased root activity and thus, increased concentration of $\mathrm{P}$ in leaves from 2 to 8 WAT.

\section{Conclusion}

$\mathrm{mg} \cdot \mathrm{L}^{-1} \mathrm{Zn}$ from 2 and 6 WAT (young to maturity), respectively, and then decreased at 8 WAT (Table 3). Although within the recommended range, lower $\mathrm{Zn}$ tissue concentra- 
tissue sufficiency ranges for $H$. hybrid. This study expands the general understanding of leaf tissue nutrient sufficiency ranges by chronological age. An overall trend of increasing tissue concentration over time was observed for $\mathrm{N}, \mathrm{P}, \mathrm{Ca}, \mathrm{S}, \mathrm{Zn}, \mathrm{Cu}$, and $\mathrm{B}$, although a decreasing trend was observed for $\mathrm{K}, \mathrm{Fe}, \mathrm{Mn}$, and $\mathrm{Al}$. The leaf tissue concentration sufficiency ranges determined in this study are narrower than those reported by Bryson and Mills (2014) and likely because of investigating only two cultivars. Therefore, further experiments including more than two cultivars of Hibiscus and other fertilizer sources is warranted. Furthermore, continued research to establish nutrient sufficiency ranges by chronological age of other popular herbaceous perennial species grown in soilless substrates during container production is needed.

\section{Literature Cited}

Barnes, J.G. 2010. Characterization of nutrient disorders of floriculture species. North Carolina State Univ., Raleigh, NC, MS Thesis.

Biernbaum, J. and M.S. Morrison. 2000. Forcing perennials: Root zone management, p. 13-16. In: Greenhouse Grower Magazine and Michigan State University (eds.). Firing up perennials: The 2000 edition. Meister Media, Willoughby, $\mathrm{OH}$.

Bryson, G.M. and H.A. Mills. 2014. Herbaceous perennials, p. 383-413. In: G.M. Bryson and H.A. Mills (eds.). Plant analysis handbook IV. Micro-Macro Publishing, Athens, GA.

Campbell, C.R. 2000. Reference sufficiency ranges for plant analysis in the southern region of the United States. Southern Coop. Ser. Bul. 394.
Dole, J.M. and H.F. Wilkins. 2005. Nutrition, p. 94-126. In: J.M. Dole and H.F. Wilkins (eds.) Floriculture: Principles and species. Pearson Prentice Hall, Saddle River, NJ.

Enfield, A.L. 2002. Flower induction and cultural requirements for quick-cropping of the herbaceous perennials Veronica spicata, Phlox paniculata, Leucanthemum Xsuperbum, Achillea, Gaura lindheimeri, and Campanula. Dept. Horticulture, Michigan State Univ., East Lansing, MI, MS Thesis.

Heins, R., A. Cameron, W. Carlson, and E. Runkle. 2000. Firing up perennials: The 2000 edition. Meister Media Worldwide, Willoughby, $\mathrm{OH}$.

Herrick, T.A. and L.P. Perry. 1997. Influence of freeze acclimation procedure on survival and regrowth of container-grown Campanula takesimana Nakai. HortTechnology 7:43-46.

Jeong, K.Y., B. Whipker, I. McCall, and J. Frantz. 2009. Gerbera leaf tissue nutrient sufficiency ranges by chronological age. Acta Hort. 843:183-190.

Kingsley-Richards, S.L. and L.P. Perry. 2011. Influence of plant age on cold hardiness of three container-grown herbaceous perennials. J. Environ. Hort. 29:163-168.

Krug, B.A., B.E. Whipker, I. McCall, and B. Cleveland. 2010. Geranium leaf tissue nutrient sufficiency ranges by chronological age. J. Plant Nutr. 33(3):339-350.

Latimer, J.G. 2016. Growth regulators for containerized herbaceous perennial plants. Ball Publishing, West Chicago, IL.

Morgan, L. 2000. Beneficial elements for hydroponics: A new look at plant nutrition. Growing Edge 11(3):40-51.

Owen, W.G. 2017. Supplemental and sole-source light and root-zone temperature influence cutting physiology, morphology, and rhizogenesis of herbaceous perennials. Purdue Univ., West Lafayette, IN, PhD Diss.
Owen, W.G., I. McCall, and B.E. Whipker. 2013. Fertilizer rates for vegetative annuals. e-Gro Alert 2-25:1-8.

Papineau, A. and B.A. Krug. 2014. Osteospermum leaf tissue nutrient sufficiency ranges by chronological age. Acta Hort. 1034:531538.

Perry, L.P. 2011. Coralbells (Heuchera) hardiness research 2010-2011. Univ. Vermont Sustainable Herbaceous Perennials Research. 14 Mar. 2017.

Pilon, P. 2006. Fertility for perennials, p. 78-31. In: P. Pilon (ed.). Perennial solutions: A grower's guide to perennial production. Ball Publishing, Batavia, IL.

Scoggins, H.L. 2005. Determination of optimum fertilizer concentration and corresponding substrate electrical conductivity for ten taxa of herbaceous perennials. HortScience 40:1504 1506.

Tolman, D.A., A.X. Niemiera, and R.D. Wright. 1990. Influence of plant age on nutrient absorption for marigold seedlings. HortScience 25:1612-1613.

U.S. Department of Agriculture (USDA). 2006. Floriculture crops 2005 summary. Natl. Agr. Stat. Serv., Washington, D.C. 3 July 2018. <http:// usda.mannlib.cornell.edu/usda/nass/FlorCrop// 2000s/2006/FlorCrop-04-26-2006.pdf>.

U.S. Department of Agriculture (USDA). 2016. Floriculture crops 2015 summary. Natl. Agr. Stat. Serv., Washinton, D.C. 3 July 2018. $<$ http://usda.mannlib.cornell.edu/usda/nass/ FlorCrop//2010s/2016/FlorCrop-04-26-2016.pdf s.

Wright, R.D. 1986. The pour-through nutrient extraction procedure. HortScience 21:227229.

Zheng, Y. and M.J. Clark. 2013. Optimal growing substrate $\mathrm{pH}$ for five Sedum species. HortScience 48:448-452. 